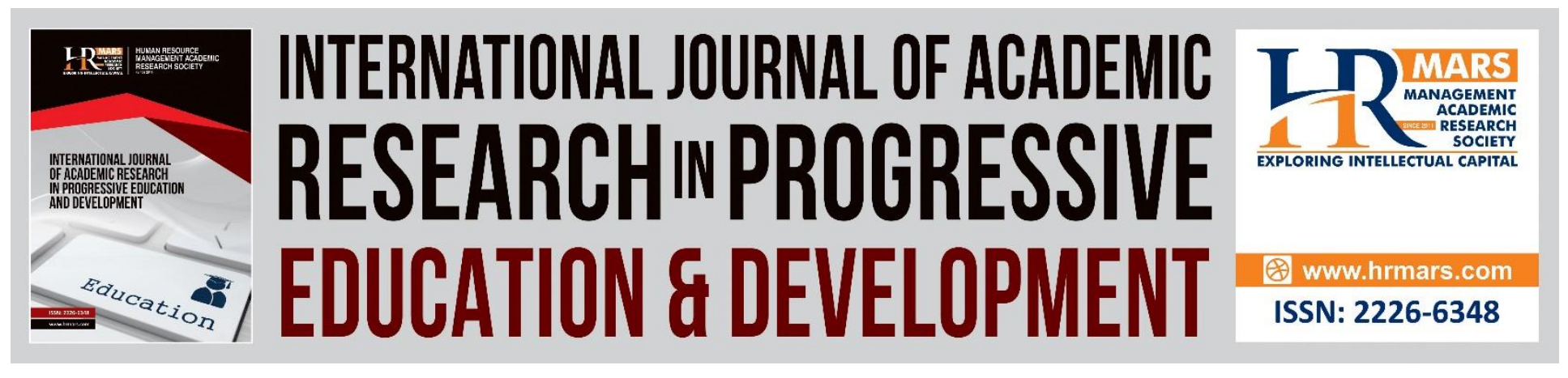

\title{
Readiness of Pre-Service Teacher to Teach Student with Special Needs through Inclusive Education Course
}

\author{
Norfishah Mat Rabi, Nor Hasnida Che Md Ghazali, Nor Aizal Akmal Rohaizad, \\ Mohd Yusof Zulkefli
}

To Link this Article: http://dx.doi.org/10.6007/IJARPED/v7-i4/4847

DOI: $10.6007 /$ IJARPED/v7-i4/4847

Received: 11 Sept 2018, Revised: 21 October 2018, Accepted: 11 Nov 2018

Published Online: 17 Nov 2018

In-Text Citation: (Rabi, Ghazali, Rohaizad, \& Zulkefli, 2018)

To Cite this Article: Rabi, N. M., Ghazali, N. H. C. M., Rohaizad, N. A. A., \& Zulkefli, M. Y. (2018). Readiness of PreService Teacher to teach Student with Special Needs through Inclusive Education Course. International Journal of Academic Research in Progressive Education and Development, 7(4), 200-210.

Copyright: (C) 2018 The Author(s)

Published by Human Resource Management Academic Research Society (www.hrmars.com)

This article is published under the Creative Commons Attribution (CC BY 4.0) license. Anyone may reproduce, distribute, translate and create derivative works of this article (for both commercial and non-commercial purposes), subject to full attribution to the original publication and authors. The full terms of this license may be seen

at: http://creativecommons.org/licences/by/4.0/legalcode

Vol. 7, No. 4, 2018, Pg. 200 - 210

http://hrmars.com/index.php/pages/detail/IJARPED

JOURNAL HOMEPAGE

Full Terms \& Conditions of access and use can be found at http://hrmars.com/index.php/pages/detail/publication-ethics 


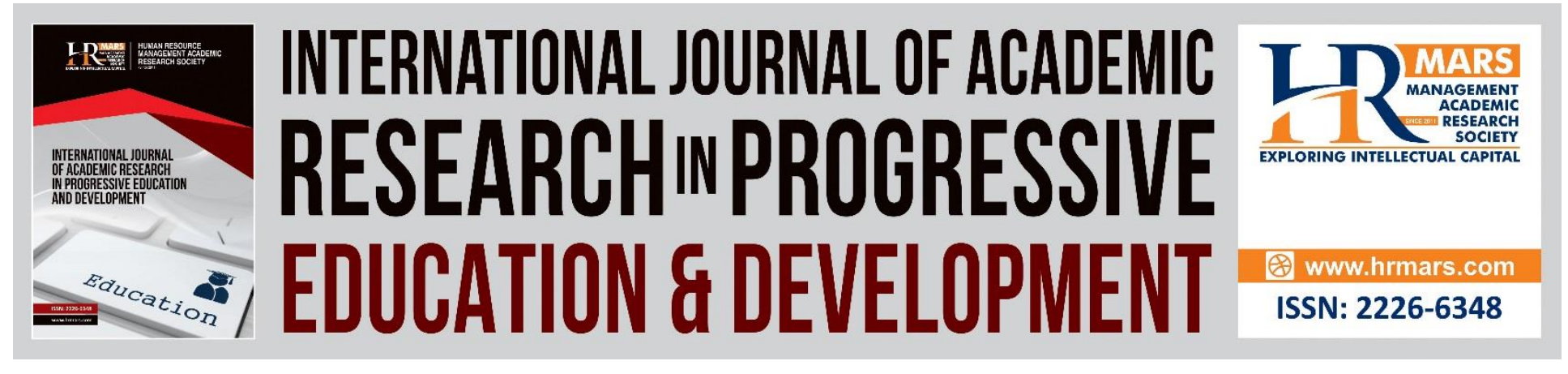

\title{
Readiness of Pre-Service Teacher to teach Student with Special Needs through Inclusive Education Course
}

\author{
Norfishah Mat Rabi ${ }^{1}$, Nor Hasnida Che Md Ghazali², Nor Aizal \\ Akmal Rohaizad ${ }^{3}$, Mohd Yusof Zulkefli ${ }^{4}$ \\ ${ }^{1,2}$ Faculty of Human Development, Universiti Pendidikan Sultan Idris, Malaysia \\ ${ }^{3}$ Faculty of Social Development and Economy, Universiti Malaysia Terengganu, Malaysia \\ ${ }^{4}$ Faculty of Arts and Social Science, Universiti Tuanku Abdul Rahman, Malaysia
}

\begin{abstract}
The purpose of this study is to identify the readiness of pre-service teacher to teach student with special needs through inclusive education course. The four objectives of the study focused on knowledge in special education and inclusive education policies, characteristics of students with special needs, inclusive models, and teaching methods. The case study was conducted at Universiti Pendidikan Sultan Idris and participants were selected purposively involving 30 preservice teachers from regular education program. The data were collected using observation, interview and document analysis. The research instrument used were multiple type of checklist and interview questions. Data were analyzed using descriptive and reference methods. Finding showed that pre-service teachers had readiness to teach students with special education needs in schools based on knowledge about special education and inclusive education policies, characteristic of students with special education needs, inclusive models, and teaching methods. The implication of the study showed that the readiness of pre-service teachers for inclusive education program is derived from the learning and training process at university level. In conclusion, pre service teacher should be trained systematically in teaching student with special needs for inclusive program in the future.
\end{abstract}

Keywords: Inclusive Education, Pre-Service Teacher, Readiness, Student With Special Needs

\section{Introduction}

Readiness to teach student with special education needs in inclusive classroom is a demand for pre-service mainstream education teacher. To teach student with special education needs in inclusive setting, teacher must have an ability to plan, control and facilitate interaction in the classroom that is appropriate to the activity and which takes into account the different needs and abilities of learners (Di Gennaro et al., 2014). It enables the teacher to manage the energy 

DEVELOPMENT

Vol. 7, No. 4, 2018, E-ISSN: 2226-6348 ๑ 2018 HRMARS

levels, ensure appropriate learners participation and create pairs and groups that have a positive impact on learning. It helps to motivate learners and ensures that different styles of learning are catered for and different needs are met. Through attending a course or a program, pre service teachers can get basic knowledge of various disabilities, their diagnosis, management and rehabilitation (Dally \& Dempsey, 2015). Skills and knowledge is very important for general education teachers to implement inclusive teaching processes successfully in their classrooms. Through specific courses or programs, they can improve the skills of managing inclusive classroom to meet the needs of special children. Through the training programs, pre service teachers will be able to distinguish between sympathy and empathy.

Many factors is identified to contribute weaknesses in teaching inclusive at school. As example, lack of understanding about inclusive education can be a barrier to inclusion. If special education teachers and general education teachers failed to have mutual understanding, inclusion is hardly to be achieved in school. It is probably caused by the failure in readiness in teaching students with special needs in inclusive setting. The study carried out by Sharma et al., (2015) uses four indicators to identify the readiness of pre-service teachers through the consideration of attitudes, efficacy, concerns and interests of pre-service teachers in the inclusive class. If teachers have the readiness, none of problem will encounter in the implementing inclusion in school. Pertaining the readiness in inclusive education, it is a must for pre-service teacher to expand knowledge and skill to be suited with the student needs in the inclusive setting. It could be many reasons underpinning the fact that some students with special needs having difficulties in participating in academic and social interaction at school. Whether the problems came from the student or from the teacher, the difficulties will affected their learning process and their social life.

\section{Literature Review}

It could be many reasons underpinning the fact that some general education teachers having difficulties in teaching academic and social interaction for special education needs student in inclusive classroom. Whether the problems came from the student or from the teacher, the difficulties will affected their learning process and their social life. Inclusive education is specially created for student with special education needs. Inclusive education is an educational program provided to children with special needs along with the mainstream students. They are integrated into a class or classroom in the same setting and learn the same curriculum. Inclusive according to Lewis and Doorlag (2011) is a place where students with special needs learning alongside mainstream students in the same setting. Caldwell (2010) finds that the benefits of full inclusive programs are that students can improve development in social and academic aspects. When in the same setting, student with special needs has the opportunity to create effective communication and social interaction with peers and people around. 21st century education systems have a clear vision for teachers who are sufficiently competent and motivated to know how to include children with special needs (and those from other marginalized groups) in all classrooms (Lewis \& Sagree, 2013).

Recently, Dempsey and Dally (2014) developed a comprehensive set of professional standards that describe the work of Australian special education teachers. Areas covered by these standards are knowing students; knowing content; planning and implementing teaching strategies; the learning environment; feedback and reporting; professional learning; engaging 

DEVELOPMENT

Vol. 7, No. 4, 2018, E-ISSN: 2226-6348 ๑ 2018 HRMARS

with others; self-efficacy; and, co-teaching and professional skills. Rouse (2008) writes that developing effective inclusive practice is not only about developing teachers' knowledge through professional learning, it is also about encouraging teachers to educate themselves in different ways and can involve challenging them to reconsider their attitudes and beliefs towards inclusive education. Knowledge and skill are required by general teachers in order to manage and track their students' learning needs in inclusive classrooms. Di Gennaro et al. (2014) recommend that teachers learn how to give value to difference, as well as how to identify the best ways to respond to diversity in their classrooms. Knowledge about special education policy, inclusive education setting, the characteristics of student with special needs and teaching method are very important to be learned by pre-service teachers before attached to school. Even if knowledge is available to teachers, it is unlikely that it will be applied if they do not have the will to do so; either because they do not believe it is their role to include all learners or they believe that their actions will not lead to positive outcomes for all students. The findings of Killoran et al., (2014) show that inclusive education courses have successfully changed the perception of pre-service teachers on inclusive programs and provide a solid foundation of knowledge to be practiced in future teaching.

Teacher also need to set an alternative expectations which is suitable for the students as example develop alternative assessments or make an appropriate expectations to be suited with student's capabilities. Beside that teacher should have an ability to determine how to modify assignments for students; how to design classroom activities with so many levels that all students have a part. This teaching skill can apply not just at the elementary or secondary level, but at the college level as well. It will mean more activity-based teaching rather than seat-based teaching. Ability to learn how to value all kinds of skills that students bring to class, not just the academic skills is also important. In doing this, teachers will make it explicit that in their classrooms they value all skills, even if that is not a clear value of a whole school. In order to provide daily success for all students, teachers have to work to counteract the message all students get when certain students are continually taken out of class for special work. Other competencies that will help general education teachers in an inclusive environment include. A realization that every child in the class is their responsibility. Teachers need to find out how to work with each child rather than assuming someone else will tell them how to educate a child. Knowing a variety of instructional strategies and how to use them effectively is a good advantage for them (Dempsey and Dally, 2014). This includes the ability to adapt materials and rewrite objectives for a child's needs. Working as a team with parents and special education teachers to learn what skills a child needs and to provide the best teaching approach.

\section{Methodology}

This case study examines specifically on the readiness of pre-service teacher (PST) to teach students with special needs (SSN) in an inclusive program. Purposive sampling is used in this study. The sample of the study is 30 pre-service teachers, range from semester 1 to semester 8 . Data were collected through interviews, observations and document analysis. An interview session was conducted to obtain qualitative data individually with pre-service teacher as a participant. Instruments used in collecting data are interviews question, checklists and field notes. Four checklists are used as a data collection tool (Special Needs Student Characteristics Checklist (SNSC), Special Education and Inclusive Education Policy Checklist (IEP), Teaching 
INTERNATIONAL JOURNAL OF ACADEMIC RESEARCH IN PROGRESSIVE EDUCATION AND DEVELOPMENT

Vol. 7, No. 4, 2018, E-ISSN: 2226-6348 @ 2018 HRMARS

Method Checklist (TM), and Inclusive Model Checklist (IMC). Documents referenced are Course Framework (CF), Teaching Design (ID), lecture notes, and assignments. This case study was analyzed and reported descriptively and supported by reference statistics.

\section{Results}

The findings refer to the readiness of pre-service teachers towards inclusion. Result is reported in four main areas: (i) special education and inclusive education policy, (ii) student with special needs characteristic, (iii) inclusive education model, and (iv) teaching techniques.

1) Special education and inclusive education policy

Special education and inclusive education policy is one of the knowledge that must be acquired by pre-service teacher in order to develop readiness for inclusion. To develop readiness, 11 subtopics were taught to pre-service teacher which were related to the special education and inclusive education policy. The participants' response regarding the readiness to teach students with special needs is shown in Table 1.

Table 1 Special education and inclusive education policy

\begin{tabular}{|c|c|l|c|c|}
\hline No & Code & Special education and inclusive education policy & \multicolumn{2}{|c|}{ Participant responce } \\
\cline { 4 - 5 } & & & Yes & No \\
\hline 1 & DSE & I know the definition of special education & 30 & 0 \\
\hline 2 & PLSE & I know the policy and law in special education & 10 & 20 \\
\hline 3 & SEP & $\begin{array}{l}\text { I know the special education program in } \\
\text { Ministry of Education in Malaysia }\end{array}$ & 20 & 10 \\
\hline 4 & TSE & I know type of special education & 15 & 15 \\
\hline 6 & DIE & $\begin{array}{l}\text { I know the concept and definition of inclusive } \\
\text { education }\end{array}$ & 30 & 0 \\
\hline 7 & EAIP & $\begin{array}{l}\text { I know the Education Act and international } \\
\text { policy }\end{array}$ & 10 & 20 \\
\hline 8 & MEDP & $\begin{array}{l}\text { I know the Malaysian Educational Development } \\
\text { Plan }\end{array}$ & 20 & 10 \\
\hline 9 & BMF & I know BIWAKO Millennium Framework & 5 & 25 \\
\hline 10 & SS & I know Salamanca Statement & 5 & 25 \\
\hline 11 & NIE & I know the needs of inclusive education & 30 & 0 \\
\hline & & Total & 175 & 120 \\
\hline
\end{tabular}

Table 1 showed that $59.32 \%$ participants were acquired knowledge about special education and inclusive education policy and $40.68 \%$ were not. Finding strongly proven that $100 \%$ participants gained knowledge in definition of special education (DSE), concept and definition of inclusive education (DIE) and the needs of inclusive education (NIE). Results showed that knowledge in DSE, DIE and NIE really help participant's readiness to teach students with special needs in inclusive setting. 66.67\% participants understand deeply about special education program in Ministry of Education in Malaysia (SEP) and Malaysian Educational Development Plan which is 
INTERNATIONAL JOURNAL OF ACADEMIC RESEARCH IN PROGRESSIVE EDUCATION AND DEVELOPMENT

Vol. 7, No. 4, 2018, E-ISSN: 2226-6348 @ 2018 HRMARS

very important to be acquired before appointed as an inclusive teacher. Nevertheless, only 16.67\% participants acquired knowledge about BIWAKO Millennium Framework (BMF) and Salamanca Statement (SS). This two topics are not compulsory for pre service teacher to learned. However from the participant's response, it is clearly showed the readiness of pre-service teacher in teaching student with special needs in inclusive setting.

2) Understanding the Characteristic of Student with Special Needs

Understanding the characteristic of student with special needs is one of the skills that must be acquired by pre-service teacher before they teach in inclusive program. To develop readiness in understanding the characteristic of student with special needs, pre-service teacher were learned 10 characteristic through the inclusive education course offered by UPSI. Table 2 showed the readiness of the participants in understanding the characteristic of student with special needs.

Table 2 Characteristic of Student with Special Needs

\begin{tabular}{|c|c|c|c|c|}
\hline \multirow[t]{2}{*}{ No } & \multirow[t]{2}{*}{ Code } & \multirow[t]{2}{*}{ Characteristic of Student with Special Needs } & \multicolumn{2}{|c|}{ Participants' responce } \\
\hline & & & Yes & No \\
\hline 1 & $\mathrm{CVI}$ & I know about children with visual impairment & 30 & 0 \\
\hline 2 & $\mathrm{CHI}$ & $\begin{array}{l}\text { I know about children with hearing } \\
\text { impairment }\end{array}$ & 30 & 0 \\
\hline 3 & $\mathrm{CPH}$ & $\begin{array}{l}\text { I know about children with physical and } \\
\text { other health problem }\end{array}$ & 30 & 0 \\
\hline 4 & CAS & $\begin{array}{l}\text { I know about children with autism spectrum } \\
\text { disorder }\end{array}$ & 20 & 10 \\
\hline 5 & CSD & I know about children with syndrome down & 30 & 0 \\
\hline 6 & $\mathrm{CD}$ & I know about children with dyslexia & 30 & 0 \\
\hline 7 & $\mathrm{CADH}$ & $\begin{array}{l}\text { I know about children with attention deficit } \\
\text { hyperactive disorder }\end{array}$ & 30 & 0 \\
\hline 8 & CGT & $\begin{array}{l}\text { I know about children with gifted and } \\
\text { talented }\end{array}$ & 10 & 20 \\
\hline 9 & CMI & $\begin{array}{l}\text { i know about children with multiple } \\
\text { impairment }\end{array}$ & 30 & 0 \\
\hline 10 & $\mathrm{CDB}$ & I know about children with deaf-blinded & 30 & 0 \\
\hline & & Total & 300 & 150 \\
\hline
\end{tabular}

Result showed that $66.67 \%$ of participants understand the characteristics of student with special needs whereas $33.33 \%$ were not understand. From the 10 subtopics learned by participants in the course, eight (8) subtopics showed the highest response in understanding the characteristic of student with special needs. The eight subtopics with $100 \%$ 'YES' response included characteristic of children with visual impairment (CVI), children with hearing impairment (CHI), children with physical and other health problem (CPH), children with syndrome down (SSD), children with dyslexia (CD), children with attention deficit hyperactive disorder (CADH), children with multiple impairment (CMI), and children with deaf-blinded (CDB). $66.67 \%$ participants 

DEVELOPMENT

Vol. 7, No. 4, 2018, E-ISSN: 2226-6348 @ 2018 HRMARS

showed less understand the characteristic of children with autism spectrum disorder (CAS) whereas only 33.33\% participants showed understand the characteristic of children with gifted and talented (CGT).

3) Inclusive Education Model

Implementation of the inclusive program in school based on inclusive education model. The model is assigned by Ministry Of education and must be followed exactly what is written in the model without doubt. This model is being used by all schools in Malaysia and is proven suitable for the inclusive program in school. Table 3 showed seven aspect of inclusive model learned by pre-service teacher in the course.

Table 3 Inclusive Education Model

\begin{tabular}{|c|c|l|c|c|}
\hline No & Code & \multicolumn{1}{|c|}{ Inclusive Education Model } & \multicolumn{2}{|c|}{ Participant's Responce } \\
\cline { 3 - 5 } & & & Yes & No \\
\hline 1 & IEM & I know inclusive education model & 30 & 0 \\
\hline 2 & TIE & I know type of inclusive education & 30 & 0 \\
\hline 3 & FIE & I know fully inclusive education & 30 & 0 \\
\hline 4 & PIE & I know partially inclusive education & 30 & 0 \\
\hline 5 & MDR & I know multi-discipline team role & 5 & 25 \\
\hline 6 & IEMn & I know inclusive education management & 10 & 20 \\
\hline 7 & IES & I know inclusive classroom setting & 10 & 20 \\
\hline & & Total & 145 & 65 \\
\hline
\end{tabular}

Table 3 showed the result of knowledge on inclusive education model. Overall, 69.05\% participants showed readiness in acquiring knowledge in inclusive model, whereas $30.95 \%$ were not acquired. From the seven aspect of knowledge, participants showed $82.76 \%$ response in inclusive education model (IEM), type of inclusive education (TIE), fully inclusive education (FIE), and partially inclusive education (PIE). For the multi-discipline team role (MDR), participants showed the lowest response $(2.38 \%)$ to the knowledge which means participant did not fully understand of MDR role. For inclusive education management (IEMn) and inclusive classroom setting (IES), finding showed only $13.79 \%$ participants understood the concept of the inclusive education model.

4) Teaching Techniques For Student With Special Needs

For successful inclusion, pre-service teachers should acquire skill in teaching methods. Readiness in teaching method means participant have to learn various aspects of skill in teaching methods. Table 4 showed 18 aspects of teaching technique to be fulfilled by participant for successful inclusion. 
INTERNATIONAL JOURNAL OF ACADEMIC RESEARCH IN PROGRESSIVE EDUCATION AND DEVELOPMENT

Vol. 7, No. 4, 2018, E-ISSN: 2226-6348 @ 2018 HRMARS

Table 4 Teaching Techniques For Student With Special Needs

\begin{tabular}{|c|c|c|c|c|}
\hline \multirow[t]{2}{*}{ No } & \multirow[t]{2}{*}{ Code } & \multirow[t]{2}{*}{$\begin{array}{l}\text { Teaching Techniques For Student With Special } \\
\text { Needs }\end{array}$} & \multicolumn{2}{|c|}{$\begin{array}{l}\text { Participant's } \\
\text { responce }\end{array}$} \\
\hline & & & Yes & No \\
\hline 1 & TM & $\begin{array}{l}\text { I know the teaching method for student with } \\
\text { special needs }\end{array}$ & 10 & 20 \\
\hline 2 & AEM & $\begin{array}{l}\text { I know the assesment and evaluation method for } \\
\text { student with special needs }\end{array}$ & 10 & 20 \\
\hline 3 & SCS & $\begin{array}{l}\text { I know the social an communiaction skill of student } \\
\text { with special needs }\end{array}$ & 10 & 20 \\
\hline 4 & CSET & $\begin{array}{l}\text { I know how to collaborate with special education } \\
\text { teacher }\end{array}$ & 10 & 20 \\
\hline 5 & NIS & $\begin{array}{l}\text { I know the needs of student with special needs in } \\
\text { inclusive setting }\end{array}$ & 10 & 20 \\
\hline 6 & MC & $\begin{array}{l}\text { I know the method of communication among } \\
\text { student with hearing impairment }\end{array}$ & 5 & 25 \\
\hline 7 & STL & $\begin{array}{l}\text { I know the use of software in teaching and } \\
\text { learning for student with hearing impairment }\end{array}$ & 0 & 30 \\
\hline 8 & BR & I know Braille & 0 & 30 \\
\hline 9 & $\mathrm{OA}$ & $\begin{array}{l}\text { I know Optic and non-Optic aids for student with } \\
\text { visual impairment }\end{array}$ & 0 & 30 \\
\hline 10 & ICT & I know ICT for student with visual impairment & 0 & 30 \\
\hline 11 & VII & $\begin{array}{l}\text { I know visual impairment and implication in } \\
\text { education }\end{array}$ & 10 & 20 \\
\hline 12 & AEM & $\begin{array}{l}\text { I know assessment and evaluation model for } \\
\text { student with special needs }\end{array}$ & 0 & 30 \\
\hline 13 & IEP & $\begin{array}{l}\text { I know Individual Educational Plan for student with } \\
\text { special needs }\end{array}$ & 10 & 20 \\
\hline 14 & SS & $\begin{array}{l}\text { I know support services for student with special } \\
\text { needs }\end{array}$ & 10 & 20 \\
\hline 15 & VGS & $\begin{array}{l}\text { I know various goverment services for student with } \\
\text { special needs }\end{array}$ & 10 & 20 \\
\hline 16 & MTS & $\begin{array}{l}\text { I know medical and therapy services for student } \\
\text { with special needs }\end{array}$ & 10 & 20 \\
\hline 17 & SSS & $\begin{array}{l}\text { I know social support services for student with } \\
\text { special needs }\end{array}$ & 20 & 10 \\
\hline 18 & PS & $\begin{array}{l}\text { I know private and NGO services for student with } \\
\text { special needs }\end{array}$ & 10 & 20 \\
\hline & & Total & 135 & 405 \\
\hline
\end{tabular}

Table 4 showed the pre-service teachers' response for the teaching methods in terms of readiness for the inclusion. Overall finding showed $25.00 \%$ participants were obtained readiness 
INTERNATIONAL JOURNAL OF ACADEMIC RESEARCH IN PROGRESSIVE EDUCATION AND DEVELOPMENT

Vol. 7, No. 4, 2018, E-ISSN: 2226-6348 ๑ 2018 HRMARS

while $75.00 \%$ were not. The highest response which were related to readiness to teach student with special needs was social support services for student with special needs (14.81\%) followed by 11 aspects of teaching methods. For the use of software in teaching and learning for student with hearing impairment and ICT for student with visual impairment, all participants were failed to obtain readiness to teach in the inclusive classroom.

\section{Discussion}

This study identified four main aspect that pre-service teacher need to acquire as well to get readiness for inclusion. The four main aspects were knowledge in special education and inclusive education policies, characteristics of student with special needs, teaching techniques, and inclusive education model. The special education and inclusive education policy is important in order to teach inclusive setting successfully. Understanding the characteristic of students' special needs is one of the important aspects in developing the willingness of pre-service teachers to teach student in an inclusive classroom. Professional development should provide teachers with the skills to identify and define special needs problems, recognize their students and understand the importance of learning the culture of students, and knowledge about disability needs (Florian, 2012; Jenkins \& Yoshimura, 2010; Nichols \& Sheffield, 2014; Philpot, Furey \& Penney, 2010). In order to improve the pre-service teacher's attitude towards inclusive, they should be given the opportunity together with special needs students (Chambers \& Lavery, 2012) so that they can understand and understand the characteristics of the students in depth.

This study proves that readiness in teaching student with special needs is important to take into consideration. The inclusive education course provides a solid knowledge to be practiced by pre-service in future work as an educator in inclusive setting. Through special inclusive education topic, pre-service teachers studied many aspect of the inclusive education, such as the concept, definition, the needs for inclusive, the models whether full-time or parttime, classroom layout (setting), and the welfare and needs of inclusive students. As mentioned by Killoran, Woronko, and Zaretsky (2014), teacher education courses which was focusing on inclusive issues had transformed perceptions and self-efficacy, and also provided basic knowledge to students towards inclusive education (Loreman, Sharma, \& Forlin, 2013). It is supported by Philpot, Furey and Penney (2010), teacher preparation programs provided by teacher training institutions should provide a full range of knowledge on inclusive education laws and policies, experience interacting with people with disabilities, the level of confidence in teaching disabled, and previous teaching and training experiences with disabilities (Loreman, Sharma, \& Forlin, 2013).

The readiness was also seen in the teaching of teaching techniques. Through this course pre-service teachers studied various topics related to teaching techniques for inclusion setting. Pre-service teachers were introduced to multiple media for special needs students such as optical and non-optical devices, Braille, various software, and ICT for students with special needs. As an inclusive teacher, it is important for pre-service teachers to be ready with knowledge regarding teaching techniques. Education management and decision-makers should think whether teachers need to know ways to improve teaching and learning process, or innovate in teaching techniques and must be exposed to various teaching strategies, including developing a record of assessment and using cognitive strategies to improve learning (Florian, 2012; Lancaster \& Bain, 2010; Philpot, Furey \& Penney, 2010). Group-based teaching strategies such as cooperative 
Vol. 7, No. 4, 2018, E-ISSN: 2226-6348 @ 2018 HRMARS

learning and peer-tutoring, support or multidisciplinary groups to facilitate student learning (Garrote, Sermier, \& Moser, 2017). Certain activities will encourage critical thinking skills, creative thinking skills, communication skills, and collaborative learning skills of students with special needs with other students. Teacher education courses should align teaching methods equally with inclusive values and support the way teachers deal with complex features in the context of the 21st century education (Di Gennaro et al., 2014). In conclusion, this study is very much important to encourage pre-service teacher to build readiness in teaching with the right teaching techniques in an inclusive setting.

\section{Conclusion}

Readiness in teaching students with special needs in inclusive program is important for preservice teachers. Before being attached in the inclusive program, they must acquire knowledge about characteristics of students with special needs, special education and inclusive education policies, teaching techniques, and inclusive education model. In encouraging pre-service teachers' readiness for inclusion, it is reasonable to offer inclusive education course at the university level. It is recommended that the inclusive education course must be taken by preservice teachers to teach in inclusive program effectively and successfully.

\section{Acknowledgement}

The authors would like to express utmost appreciations to the Research Management and Innovation Center (RMIC) for the allocation of the Research Grant University.

\section{Corresponding Author}

Norfishah Mat Rabi,

Faculty of Human Development, Universiti Pendidikan Sultan Idris,

Malaysia

Email: norfishah@fpm.upsi.edu.my

\section{Reference}

Boyle, C., Topping, K., \& Jindal-Snape, D. (2013). Teachers' attitudes towards inclusion in high schools. Teachers and Teaching Theory and practice. 19(5), 527-542.

Chambers, D. J., \& Lavery, S. D. (2012). Service-learning: A valuable component of pre service teacher education. Australian Journal of Teacher Education, 37(4).

Dempsey, I.J. \& Dally, K (2014). Professional Standards for Australian Special Education Teachers. Australasian Journal of Special Education 38(1):1-13

Di Gennaro, D. C., Pace, E. M. \& Iolanda, Z. \& Aiello, Z. (2014). Teacher capacity building through critical reflective practice for the promotion of inclusive education. Problems of Education in the 21st Century, 60, 54-65.

Florian, L. \& Linklater, H. (2010). Preparing teachers for inclusive education: using inclusive pedagogy to enhance teaching and learning for all. Cambridge Journal of Education. 40 (4), 369-386.

Florian, L. (2012). Teacher education for inclusion. In C. Forlin (Ed.), Future Directions for Inclusive Teacher Education (pp. 212-220). Oxon, UK.: Routledge. 
INTERNATIONAL JOURNAL OF ACADEMIC RESEARCH IN PROGRESSIVE EDUCATION AND DEVELOPMENT

Vol. 7, No. 4, 2018, E-ISSN: 2226-6348 @ 2018 HRMARS

Forlin, C. (2003). Pre-service teacher education: Involvement of students with intellectual disabilities. International Journal of Learning. 10, 317-326

Garrote, A., Sermier Dessemontet, R., Moser Opitz, E. (2017). Facilitating the social participation of pupils with special educational needs in mainstream schools: A review of school-based interventions. Educational Research Review, Vol. 20, No. 1, 12-23.

Jenkins, A. \& Yoshimura, J. (2010). Not another in-service! Meeting the special education profesional development needs of elementary general educators. Teaching Exceptional Children (May/June), 36-43.

Killoran, I., Woronko, D. \& Zaretsky, H. (2014). Exploring pre service teachers' attitudes towards inclusion. International Journal of Inclusive Education, 18(4), 427-442.

Lancaster, J. \& Bain, A. (2010). The design of pre-service inclusive education courses and their effects on self-efficacy: A comparative study. Asia-Pacific Journal of Teacher Education, 38(2), 117-128.

Lewis, R.B. \& Doorlag, D. H. (2011). Teaching students with special needs in general education classrooms. 8th Ed. New Jersey: Pearson Education, Inc.

Loreman, T., Sharma, U., \& Forlin, C. (2013). Do pre-service teachers feel ready to teach in inclusive classrooms? A four-country study of teaching self-efficacy. Australian Journal of Teacher Education, 38 (1), Article 3. Available at: http://ro.ecu.edu.au/ajte/vol38/iss1/3 http://dx.doi.org/10.14221/ajte.2013v38n1.10

Nichols, S. C. \& Sheffield, A. N. (2014). Is there an elephant in the room? Considerations that administrators tend to forget when facilitating inclusive practices among general and special education teachers. National Forum of Applied Educational Research Journal, 27(1\&2), 31-44.

Philpot, D. F., Furey, E. \& Penney, S.C. (2010). Promoting leadership in the ongoing profesional development of teachers: Responding to globalization and inclusion. Exceptionality Education International 20(2), 38-54

Rouse, M (2008). Developing Inclusive Practice: A Role for Teachers and Teacher Education?. Education in the North, 16.

Sharma, U. (2011). Changing heart, head, and hands of teachers to teach in inclusive classrooms: Why and how? Bangladesh Education Journal, 10(2), 7-18.

Sharma, U., Forlin, C., Deppeler, J., \& Guang-xue, Y. (2012). Reforming teacher education for inclusion in developing countries in the Asia Pacific Region, Asian Journal of Inclusive Education, 3-16.

Sharma, U., Simi, J., \& Forlin, C. (2015). Preparedness of Pre-service Teachers for Inclusive Education in the Solomon Islands. Australian Journal of Teacher Education, 40(5).

Walton, E., Nel, N.H., Muller, H. \& Lebeloane, O. (2014). You can train us until we are blue in our faces, we are still going to struggle: Teacher professional learning in a full-service school. Education as Change, 18(2), 319-333. 